\title{
Can set influence retrieval?
}

ROBERT B. MCCALL 1

UNIVERSITY OF ILLINOIS

\begin{abstract}
An attempt was made to show that setcould influence retrieval apart from original learning. The results suggested that if learning was not too distinctive, a set change to a list which $S$ thought he could forget was disruptive to recall.

\section{Introduetion}

The literature on the role of set in learning and memory (Adams, 1961; Irion, 1948; McLaughlin, 1965; Postman, 1964) has not been concerned with whether or not set variables affect learning or retrieval apart from original learning. This study explored the latter possibility.

\section{Method}

Subjects

Forty male and 40 female undergraduates serving a course requirement were Ss. Two additional Ss were discarded because of illness and diagnosis of the experimental treatment.

Material.

Twenty CVC syllables were selected from Noble's 1961 list and were homogeneous with respect to association $(.84-.92)$, rated associations $(2.60-2.74)$, and meaningfulness (2.46-2.59). The $20 \mathrm{CVC}$ 's, only two of which began with the same letter, were randomly divided three separate times into pairs of two 10-item lists. The lists of a pair were typed in parallel vertical columns on 3 by 5 in cards, and were plainly labeled "List 1 " and "List 2." The columns of two of the pairs were transposed, left to right and reverse, producing a total of five arrangements with lists balanced for syllables, and each pair was given to two Ss in each of four groups in a 2 by 2 design.

Procedure.

Table 1 presents a synopsis of the procedure. Essentially, Ss were given $7 \mathrm{~min}$. to learn the syllables in the two lists in any manner they chose. This was followed by an audible addition task and a written free recall of one of the lists.

The four treatment groups (BS, BC, ES, EC) were formed by instructions. Half the Ss were told before learning that they would have to recall both of the lists (B), while the other half were told that either one or the other list would be required but not both (E) as described in Event 1, Table 1. Each of these two groups was further subdivided (Event 5). Half the Ss were told just prior to the recall but after original learning that contrary to the instruction given just before the addition task which informed them that List 1 (for example) would be required (Event 3), the recall listdesignation had been changed to List 2 in this case (C). The remaining Ss received no such change of instruction
Table 1. Instructions and Procedure

\begin{tabular}{|c|c|c|}
\hline Event & Time (Min.) & Procedure or Instruction \\
\hline 1. & & $\begin{array}{c}\text { B Groups: "You'll have to recall both } \\
\text { lists." } \\
\text { E Groups: "You'll have to recall either } \\
\text { one or the other list, not } \\
\text { both." }\end{array}$ \\
\hline 2. & $0: 00 \cdot 7: 00$ & $\begin{array}{l}\text { Learning: All Ss given one card contain- } \\
\text { ing two lists of } 10 \mathrm{CVC} \text { s each. Ss told } \\
\text { when } 2 \frac{1}{2} \text { and } 5 \mathrm{~min} \text {. had elapsed. }\end{array}$ \\
\hline 3. & $7: 00-7: 07.5$ & $\begin{array}{l}\text { All Ss: "You'll have to recall List 1(2). } \\
\text { Add the se numbers rapidly out loud." }\end{array}$ \\
\hline 4. & $7: 07.5-7: 22.5$ & Addition task \\
\hline 5. & $7: 22.5-7: 30$ & $\begin{array}{c}\text { S Groups: "Go ahead and recall List } \\
1(2) . "\end{array}$ \\
\hline & & $\begin{aligned} \text { C Groups: "I'm changing the list des- } \\
\text { ignation. Instead of List } 1(2), \\
\text { recall now List } 2(1) . "\end{aligned}$ \\
\hline 6. & $7: 30-9: 00$ & Written, free recall. \\
\hline
\end{tabular}

and recalled the same list that had been designated earlier (S). Which list was actually recalled, "List 1" or "List 2," was counterbalanced for each group within the limits of the experiment, as were the particular syllables and the sex of $\mathrm{S}$.

Hence, the assumption was that the audible addition would prevent rehearsing, and the question examined was whether or not the change in retrieval set induced by altering the instructions after original learning would affect free recall.

\section{Results}

While the design lent itself to analysis of variance, each of the four groups received a markedly different psychological treatment from the standpoint of traditional interference theory. Hence, individual comparisons with simple effects tests was the major mode of analysis. Further, in order to correct in some way for response biases and excessive guessing, analyses were carried out on $\mathrm{X}=$ (Number Correct) $-1 / 2$ (Number Incorrect), in which a syllable had to be perfectly reproduced to be counted as correct.

Although there was no general accuracy difference between Ss recalling List 1 (left-hand side of the stimulus card) and those recalling List $2(F<1)$, the two groups behaved quite differently and will be discussed separately.

Table 2 shows the means for all groups. Clearly, there were no differences for Ss recalling List 1. However, for Ss recalling List 2, simple effects tests revealed that the EC group was poorer than the $\operatorname{ES}(F=9.39$, $\mathrm{df}=1 / 36, \mathrm{p}<.01), \mathrm{BS}(\mathrm{F}=4.90, \mathrm{df}=1 / 36, \mathrm{p}<.05)$, and $\mathrm{BC}(\mathrm{F}=4.00, \mathrm{df}=1 / 36, \mathrm{p}<.06)$ groups. 
Table 2. Means for All Groups

\begin{tabular}{lcccc} 
& BS & BC & ES & EC \\
\hline Recalled List 1 & 7.05 & 7.15 & 7.30 & 7.35 \\
Recalled List 2 & 7.00 & 6.75 & 8.00 & 4.40 \\
\hline
\end{tabular}

\section{Discussion}

The important result was that for Ss recalling the right-hand column on the card (List 2), if the change in instruction was to a list which the $\mathrm{S}$ thought he could forget, the change was detrimental to recall; if, however, the change was to a list which S presumably thought he would have to recall later anyway, it was not. Furthermore, since the BS-BC difference was negligible, it is unlikely that the change of instruction per se was disruptive; rather it was effective only in conjunction with the $\mathrm{E}$ treatment.

The question, however, was why there were absolutely no effects for Ss recalling List 1 when the actual syllables were counterbalanced for left-right position and there was no general advantage to recalling List 1 or 2. It was evident from observation and post-test questioning that Ss learned List 1 first, and then List 2. Moreover, Ss were encouraged by implication to review the lists during the last two minutes of original learning, since they were told when $2-1 / 2$ and $5 \mathrm{~min}$. of their 7-min. total had elapsed. Thus, it may be assumed that List 1 was initially learned without interference from List 2, and that it was learned in a more dist 1 ibuted fashion, the review coming a longer time after original learning than for List 2. Consequently, it appears that although not learned more accurately, the learning of List 1 was less encumbered by interference which made it more resistant to the interfering effects of changes in set.

Therefore, the data raise the question as to whether set-for-retrieval may influence recall apart from learning if the task material is not learned too distinctively. The methodological difficulty is in devising two tasks, or task aspects, which can be learned simultaneously and equally well and to be able to control original learning.

\section{Heferences}

Adams, J. A. The second facet of forgetting: A review of warm-up decrement. Psychol. Bull., 1961, 58, 257-273.

Irion, A. L. The relation of "set" to retention. Psychol. Rev. $1948,55,336-341$.

McLaughlin, B. "Intentional" and "incidental" learning in human subjects: The role of instructions to learn and motivation. Psychol. Bull., 1965, 63, 359-376.

Noble, C. E. Measurements of association value (a), rated associations (a'), and scaled meaningfulness (m') for the $2100 \mathrm{CVC}$ combinations of the English alphabet. Psychol. Rep., 1961, 8, 487-521. Monogr. Suppl. 3-V8.

Postman, L. Short-term memory and incidental learning. In A. W. Melten (Ed.), Categories of human learning. New York: Academic Press, 1964. Pp. 145-201.

\section{Note}

1. Now an NSF Postdoctoral Fellow at Harvard University, Department of Social Relations. The author wishes to thank Drs. J. A. Adams and L. J. Goldsmith for their comments during an early phase of this research. This work was supported in part by a USPHS Traineeship and a NIH Predoctoral Fellowship to the author. 